\title{
Digital Transformation of Enforcement Proceedings: Russian Experience
}

\author{
G.E. Ageeva ${ }^{1, *}$ \\ *Corresponding author: galinaageevva@mail.ru. \\ ${ }^{1}$ Samara State University of Economics, Samara, Russia
}

\begin{abstract}
In this study, the author considers the main problems of digital modernization concerning enforcement proceedings in the Russian Federation. Generation and further enhancement of the digital space have determined the vector of legal regulation in the implementation of any social processes several years ago. Various aspects of the economic, legal and other spheres of public life were reformed. Changes in various areas of enforcement proceedings occurred in stages, sequentially and in plain consideration with the specific features of legal relationships. However the digital transformation of enforcement proceedings has not yet come to its final stages. Many researchers note the "unavailability" of both legislation and law enforcement procedure for the changes that are taking place as well as to the final establishment of such changes as the basic and fundamental rules of law enforcement. In addition, the existing fragmentary regulation in the process of law enforcement gave rise to many problems. In this article the author attempts to identify the positive and negative experience of digital modernization of Russian law enforcement practice and define suggestions that could improve the process.
\end{abstract}

Keywords: law enforcement, digital transformation, digital economy, legal process.

\section{Introduction}

Digital transformation as a process of changing the technological and cyberspace, its ubiquitous implementation into various social processes is based not only on digital technologies, but rather on new principles of human consciousness and communication [1]. Of course, neither law enforcement practice nor legal process as a whole shall remain aloof from the changes.

The digital transformation of the legal regulation of the economic relations of Russian society entrenched not so long ago. In 2017 the Government of the Russian Federation approved the program "Digital Economy of the Russian Federation [2], which soon expired [3] due to the emergence of a national passport in the domestic legal system dedicated to the digital economy [4]. Attempts to consolidate the new informational and technological implementation for law enforcement processes in Russian society have taken place more than a decade ago.

Judicial proceedings in the Russian Federation, as one of the most fundamental blocks of law enforcement, underwent legislative reform in the light of the formation of uniform technological processes in Soviet times [5]. It is, first, about the need to create a single digital base that meets the requirements of technological advancements, information capability and uninterruptedness. The process has been continuously improved, the course on the use of information and communication technologies in the administration of justice has been clearly set now [6]. Scientific discussions on this subject also do not lose their relevance [7].

The digital transformation has affected not only legal proceedings, but also other law enforcement practices. However, despite close attention to the digital content of various legal procedures, they do not occur in any area of law enforcement without any problems.

\section{Problem Statement}

The digital transformation of domestic law enforcement practice is consistently considered to be more than just the goal of legal regulation. These are the realities of our society. The goal is rather its further dissemination, improvement and the creation of the rules for the unhindered implementation of new information and technological methods for the interaction of subjects of law.

Unfortunately there is now a significant number of problems of legal regulation uncertainty, unclear enforcement process using new digital technologies [8]. In order to resolve them it is necessary, first of all, to understand the legal nature of modern technologies, the essence of digital legal relations generated by them and to develop common models of legal regulation and principles of law enforcement in the context of the digital transformation of Russian society [9].

\section{Research Questions}

In the process of researching the features of the digital transformation of the law enforcement proceedings it seems necessary to analyze the peculiarities of the info communicative interaction of legal entities, one of which is an 
individual or collective person having state-power functions. Modern scholars note a number of significant problems in such legal procedures. This, firstly, is due to the fact that legal regulation does not keep pace with the actual dynamics of social legal relations. In addition there are no unified and clear criteria at the state level for determining either the place of modern technologies in the legal array or the legitimate ways to use them. For example, for a long time in our country law enforcement agencies refused to recognize the legal status of virtual currency (cryptocurrencies) as instrument of payment [10]. Litigation here took the lead prompting cryptocurrency to become a financial instrument [11]. However, it is currently impossible to use the specified means of payment in the practice of enforcement, since the procedure for the enforcement of foreclosure on it has not yet been provided. This is explained by the lack of technical ability to access the owner's crypto wallet due to the unforeseen procedure for technological circulation in the financial markets of previously unrecognized cryptocurrencies.

\section{Purpose of the Study}

The purpose of the study of the features of the Russian experience of digital transformation of law enforcement practice is the need to analyze and generalize the available data baggage. The above is a relevant and necessary element for the development of unified rules for the legal regulation of information and communication interaction of entities. In addition it is important to the research process that the state-imperious participant is a mandatory subject of law enforcement considered as a type of legal process. That is why it seems significant to generalize and analyze the experience of legal activity with the participation of a public administration entity, the regulation of which is currently fragmented [12].

\section{Research Methods}

In this study the author used the method of materialistic dialectics as a fundamental way of cognition and analysis. In the process of writing the article an extensive layer of law enforcement practice in various fields was studied. For the research such methods of scientific study were used: analysis and synthesis; induction and deduction. In addition, the method of comparative jurisprudence had a significant impact on the formulation of the provisions of this work, which allowed us to identify the general and distinctive features of the digital transformation of law enforcement practice, and due to it, it became possible to draw the main conclusions.

\section{Results}

Legislation and law enforcement aren't keeping up with the development of digital technologies in modern society. This conclusion was reached by experts of the BRICS Antimonopoly Center and leading world scientists [13]. The above confirms the problem of digital transformation of a particular case of law enforcement practice. However, this expression can reflect any legal relationship.

The digital transformation of certain spheres of public life which began several years ago and is currently incomplete inevitably affects a person, since it is, above all, about new principles of human consciousness and communication. Legal regulation in this case should not be fragmentary, but consistent: first, it is necessary to develop common approaches to understanding the status and place of the latest technologies in the legal sphere.

The first thing to focus on is the problem of digital literacy of legal entities [14]. For successful and effective use of modern technological methods of interaction subjects should be at least familiar with them. In our opinion, it is necessary for legal professionals to introduce mandatory digital literacy courses for further implementation in law enforcement practice.

However, it is important to emphasize that while some entities, lacking sufficient digital literacy, are trying to participate in law enforcement using modern information and communication technologies, others are already able to abuse this literacy. In view of this, at the present stage of development of Russian society, an increase in the level of the fight against cybercrime and ensuring information security is also required.

In addition, another problem of the digital transformation of domestic law enforcement is the inaccessibility of certain technologies. So, for example, e-justice is gaining momentum, in the process of judicial proceedings, subjects are increasingly interacting remotely. However, in some cases, not throughout our country, uninterrupted provision of electronic digital broadcasting is possible. And in some cases, this requires additional resources: both technological and financial. For example, to carry out a number of procedural steps, it is necessary to use an electronic digital signature, which, due to its high cost, is not yet widely used [15]. In our opinion, it is necessary to comprehensively develop and disseminate modern digital technologies in our country, as well as reduce their cost.

To reach the unhindered implementation of law enforcement practice, in consideration with its digital content in our country at the present stage, a comprehensive, science-based discussion of the essence of digital technologies in law and the procedure for their clear and consistent implementation is necessary. The regulation should differ in certainty and compliance with the actual legal relations, the interests of society and the state. 


\section{Conclusion}

The digital transformation of law enforcement practice in the Russian Federation has in fact happened but has not yet been completed and this is the reality we are facing now. However, there is currently many problems with the implementation of many procedures using the latest technologies. Law enforcement practice is ahead of legal regulation that is not complete in reflecting actual state of things. Currently, fundamental work is required in this area to develop unified positions, firstly, in understanding of information and communication tools in the legal array, secondly, in the procedure for using these technologies, and thirdly, in ways to ensure safety of digital interaction of legal entities. However, for starters, in our opinion, it is necessary to increase the digital literacy of legal entities and, if possible, provide them with unhindered access to modern technologies.

\section{References}

1. Institute of State and Law RAS, The transformation of law in the digital age (2019). URL: http://igpran.ru/download/\%D0\%A4\%D0\%BE\%D1\%80\%D1\%81\%D0\%B0\%D0\%B9\%D1\%82\%2021-032019.pdf. Accessed: 05.09.2019. [in Rus.].

2. The order of the Government of the Russian Federation of July 28, 2017 N 1632-r "On approval of the program "Digital Economy of the Russian Federation" (2017). http://www.consultant.ru/document/cons doc LAW 221756/. Accessed: 05.09.2019.

3. The order of the Government of the Russian Federation of February 12, 2019 No. 195-r "On recognition of the expiration of the order of the Government of the Russian Federation of July 28, 2017 N 1632-r" (2019). URL: http://www.consultant.ru/document/cons doc LAW 318450/. Accessed: 05.09.2019.

4. The passport of the national program "Digital Economy of the Russian Federation", approved by the Presidium of the Presidential Council for Strategic Development and National Projects, protocol No. 16 of December 24, 2018 (2018). URL: http://www.consultant.ru/document/cons_doc_LAW_319432/. Accessed: 05.09.2019.

5. M.V. Chizhov, The use of information and communication technologies in judicial activities in the context of the formation of the information society. Ph.D. thesis. Moscow: Russian State University of Justice (2013). [in Rus.].

6. Decree of the Government of the Russian Federation of December 27, 2012 N 1406 (as amended on December 24, 2018) "On the federal target program" Development of the Russian judicial system for 2013 - 2020" (2012). URL: http://www.consultant.ru/document/cons_doc_LAW_140638/. Accessed: 05.09.2019.

7. D.V. Belousov, E-justice and its role in the organization of judicial protection in Russia, Administrator of the Court. URL: http://xn----7sbbaj7auwnffhk.xn--p1ai/article/13858. Accessed: 05.09.2019. (2015). [in Rus.].

8. V.B. Naumov, Law in the era of digital transformation: in search of solutions. Russian Law: Education, Practice, Science, 6, 4-11 (2018). [in Rus.].

9. G.E. Ageeva, Legal process and "digital right". In G.R. Khasaev. S.I. Ashmarina (Eds.), Proceedings of the VII AllRussian Scientific and Practical Conference «Russian Science: Actual Research and Development» (pp. 324-328). Samara: SSUE (2019). [in Rus.].

10. G.E. Ageeva, P.P. Lang, A.V. Loshkarev, T.V. Chugurova, E.N. Churakova, Peculiarities of protecting the rights of participants of financial markets in court. In E.G. Popkova (Ed), The Future of the Global Financial System: DownFall or Harmony. Lecture Notes in Networks and Systems, 57 (pp.545-552). Cham: Springer International Publishing (2018).

11. E. Litova, A. Mikheeva, A. Krivorotova, The court first recognized cryptocurrency property. RBC. URL: https://www.rbc.ru/finances/07/05/2018/5af0280d9a7947165a6e8c22. Accessed: 05.09.2019. [in Rus.].

12. N.E. Dmitrieva (Ed.), The digital transformation of public administration: Myths and reality (HSE, Moscow, 2019). [in Rus.].

13. Federal Antimonopoly Service (FAS), The development of the digital economy is ahead of legislation and law enforcement (2019).URL: https://fas.gov.ru/news/28360. Accessed: 05.09.2019. [in Rus.].

14. N.D. Berman, On the issue of digital literacy. Modern Studies of Social Problems, 8(6-2), 35-38 (2017). [in Rus.].

15. O.V. Shemetova, S.V. Chugunova, Some problems of application of the digital signature in administrative activity of the enterprises and way of their decision. Actual Problems of Aviation and Astronautics, 3, 425-427 (2017). [in Rus.]. 